\title{
BUDGET LOANS AND SUBSIDIES TO REGIONS: WHO AND HOW MUCH RECEIVED IN 2015? ${ }^{1}$

\author{
A.Mamedov, E.Fomina
}

The volumes of financial aid extended by the federal budget via instruments of budget loans ${ }^{2}$ and grants designed to secure regional budgets balance (hereinafter - grants designed to balance regional budgets) in 2015 contracted against 2014 volumes, meanwhile their decline rates differ considerably. For example, the volume of budget loans (balance) across the Russian Federation as a whole fell by $1 \%$ in nominal terms meanwhile that of grants designed to properly balance regional budgets contracted by $34 \%$ (43\% less the Crimea). Distribution of budget loans and grants designed to balance regional budgets among the subjects is defined by significant unevenness. In 2015, around $70 \%$ of the total budget loans volume were distributed among 20 subjects of the Russian Federation (out of 85). Grants designed to balance regional budgets were also distributed unevenly: nearly $60 \%$ of their total volume were received by 20 regions in 2015.

In 2015, the RF subjects received via budget loans about Rb 167.4bn (balance including repayments) and grants aimed to balance regional budgets around $\mathrm{Rb} 152.4 \mathrm{bn}$. Consequently, via these two instruments of "prompt" financial support to regional budgets as a whole, the federal budget allocated comparable amounts. How these volumes were distributed among RF subjects: financial support was provided to the same regions or different groups of regions.

In 2015 , around $70 \%$ of the overall volume of budget loans were distributed among 20 RF subjects (of 85), which speaks about their high distribution unevenness across regions (Table 1). Khabarovsk Krai and Kirov oblast got the highest volume of budget loans: Rb 9bn each region. Distribution of grants intended to balance regional budgets was also uneven: around $60 \%$ of the total volume of grants in 2015 were received by 20 regions. Chechen Republic (around Rb 20bn) and Republic of Crimea (about Rb 17bn) display a significant gap regarding grants aimed to balance budgets.

Unevenness of the allocation of "prompt" financial aid, significant part of which is already being distributed during the federal budget execution is considered to be a normal practice. Theoretically, these types of aid should be granted to the regions facing maximum problems in their budgets execution. As a result, for further analysis we have selected two major indicators, which determine problems in the budget sphere of the RF subjects: debt burden including the share of commercial debt and dynamics of tax and non-tax revenues (revenues less interbudgetary transfers). They are easily verified by budget statistics and totally comparable among regions (i.e. it is possible to verify justification of the fact why one region received more funds than another did).

1 This paper was originally published in Online Monitoring of Russia's Economic Outlook No.3(21).

2 Balance (receipt minus repayment) of budget loans from other budgets of the budgetary system. 
Table 1

RF SUBJECTS WHO RECEIVED LARGEST AMOUNTS OF BUDGET LOANS IN 2015, RB MN

\begin{tabular}{|c|c|c|c|}
\hline RF subjects & 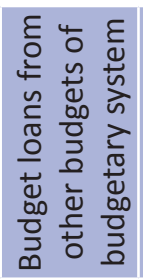 & RF subjects & 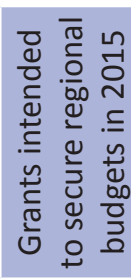 \\
\hline Total for all RF subjects & 167354 & Total for all RF subjects & 152369 \\
\hline $\begin{array}{l}\text { Total for } 20 \text { subjects with } \\
\text { largest volume of financing }\end{array}$ & 114966 & $\begin{array}{l}\text { Total for } 20 \text { subjects with } \\
\text { largest volume of financing }\end{array}$ & 92299 \\
\hline including: & & including: & \\
\hline Khabarovsk Krai & 9351 & Chechen Republic & 20413 \\
\hline Kirov oblast & 9166 & Republic of Crimea & 16970 \\
\hline Republic of Tatarstan & 8938 & Krasnodar Krai & 5738 \\
\hline Kaluga oblast & 8477 & City of Sebastopol & 4804 \\
\hline Krasnoyarsk Krai & 7581 & Irkutsk oblast & 4231 \\
\hline Perm Krai & 7479 & Samara oblast & 4178 \\
\hline Yaroslavl oblast & 6358 & Republic of Dagestan & 3271 \\
\hline Chuvash Republic - Chuvashia & 5544 & Nizhny Novgorod oblast & 3095 \\
\hline Sverdlovsk oblast & 5494 & Primorsky Krai & 2967 \\
\hline Republic of Komi & 4973 & Rostov oblast & 2823 \\
\hline Stavropol Krai & 4857 & Omsk oblast & 2695 \\
\hline Volgograd oblast & 4841 & Republic of Bashkortostan & 2546 \\
\hline Primorsky Krai & 4724 & Moscow Oblast & 2541 \\
\hline Arkhangelsk oblast & 4434 & Perm Krai & 2484 \\
\hline Kursk oblast & 4385 & Khabarovsk Krai & 2473 \\
\hline $\begin{array}{l}\text { Republic of North } \\
\text { Ossetia - Alania }\end{array}$ & 4084 & Sverdlovsk oblast & 2353 \\
\hline Zabaikalsky Krai & 3931 & Novosibirsk oblast & 2267 \\
\hline Tver oblast & 3674 & Krasnoyarsk Krai & 2216 \\
\hline Astrakhan oblast & 3347 & Arkhangelsk oblast & 2121 \\
\hline Samara oblast & 3329 & Chelyabinsk oblast & 2114 \\
\hline $\begin{array}{l}\text { Share of funds allocated to } \\
\text { subjects with highest volume } \\
\text { of financing, \% of total vol- } \\
\text { ume across RF as a whole }\end{array}$ & $68.7 \%$ & $\begin{array}{l}\text { Share of funds allocated to } \\
\text { subjects with highest volume } \\
\text { of financing, \% of total vol- } \\
\text { ume across RF as a whole }\end{array}$ & $60.6 \%$ \\
\hline
\end{tabular}

Note. By semi-bold type are identified those RF subjects, which are on the list of regions with maximum volume of both budget loans and grants intended to balance budgets.

Sources: Federal Treasury, authors' calculations.

Table 1 shows that 7 out of $33^{1}$ regions received maximum volumes regarding both financial instruments. Therefore, on the whole we cannot say that one and the same regions received financial support via two reviewed instruments.

Table 2 provides a list of 24 RF subjects grouped depending on the state of debt burden as of early 2015 (over $80 \%$ ). Among them, a group of $5 \mathrm{RF}$ subjects is identified with high share of commercial debt (over $62 \%$ - average indicator for Russia without Moscow, and Crimea Federal District) in the structure of regional debt. In the table, budget loans and grants intended to balance regional budgets are on per capita basis, which allows to ensure bet-

$133=20+20-7$ regions including the fact that 7 regions are on both lists. 
ter comparability of identified regions with financing volumes (i.e. rate fixing was implemented). With the help of analysis of data given below, we will try to answer two questions:

1. Is there a correlation between the level of a region's budget debt burden as of the beginning of 2015 and volumes of financial support via instruments of budget loans and grants designed to balance regional budgets in 2015;

2. Did regions with maximum debt burden (especially with a large share of commercial debt in the overall debt volume) have an advantage in receiving support via budget loans? Whether they were able to replace an expensive in servicing commercial debt (bank loans and debentures) with cheap budget loans.

Table 2

\section{VOLUME OF BUDGET LOANS AND GRANTS INTENDED TO BALANCE REGIONAL BUDGETS (PER CAPITA) IN 2015 IN RF SUBJECTS} WITH HIGH DEBT BURDEN

\begin{tabular}{|c|c|c|c|c|c|c|}
\hline RF subject & 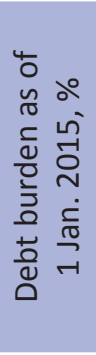 & 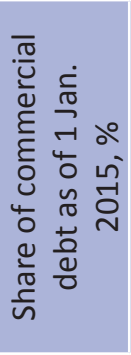 & 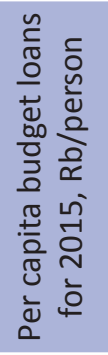 & 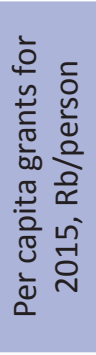 & 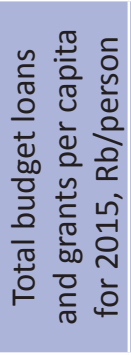 & 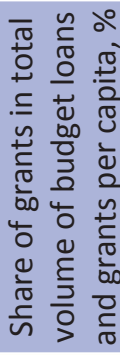 \\
\hline $\begin{array}{l}\text { Regions with debt } \\
\text { burden over } 80 \% \text { and } \\
\text { with share of commercial } \\
\text { debt in total debt } \\
\text { volume above } 62 \%\end{array}$ & 92 & 68 & 3291 & 1294 & 4585 & 28 \\
\hline Republic of Khakasia & 86 & 71 & 590 & 1189 & 1779 & 67 \\
\hline Udmurt Republic & 95 & 69 & 810 & 942 & 1752 & 54 \\
\hline Arkhangelsk oblast & 101 & 68 & 3278 & 1957 & 5235 & 37 \\
\hline Zabaikalsky Krai & 88 & 66 & 3616 & 1864 & 5480 & 34 \\
\hline Kirov oblast & 85 & 64 & 7029 & 752 & 7781 & 10 \\
\hline $\begin{array}{l}\text { Over } 80 \% \text { of debt } \\
\text { burden and below } 62 \% \\
\text { of commercial debt }\end{array}$ & 100 & 49 & 925 & 1049 & 1974 & 53 \\
\hline Amur oblast & 98 & 62 & 99 & 1527 & 1626 & 94 \\
\hline Ryazan oblast & 99 & 59 & 581 & 586 & 1167 & 50 \\
\hline Kostroma oblast & 121 & 58 & 1304 & 1594 & 2898 & 55 \\
\hline Republic of Mari El & 95 & 58 & -1485 & 607 & -877 & - \\
\hline Novgorod oblast & 83 & 58 & 2835 & 506 & 3341 & 15 \\
\hline Penza oblast & 87 & 55 & 0 & 901 & 901 & 100 \\
\hline Republic of Karelia & 119 & 55 & 1064 & 3026 & 4090 & 74 \\
\hline Pskov oblast & 88 & 55 & 504 & 799 & 1303 & 61 \\
\hline Vologda oblast & 100 & 54 & 1031 & 704 & 1735 & 41 \\
\hline Orel oblast & 86 & 54 & 1446 & 915 & 2361 & 39 \\
\hline $\begin{array}{l}\text { Republic of North } \\
\text { Ossetia - Alania }\end{array}$ & 115 & 52 & 5784 & 1050 & 6835 & 15 \\
\hline Saratov oblast & 100 & 51 & 270 & 702 & 972 & 72 \\
\hline Belgorod oblast & 106 & 48 & 1256 & 1192 & 2448 & 49 \\
\hline Smolensk oblast & 116 & 46 & 3057 & 569 & 3626 & 16 \\
\hline Krasnodarskysky Krai & 93 & 45 & 499 & 1052 & 1551 & 68 \\
\hline $\begin{array}{l}\text { Karachaevo- } \\
\text { Cherkessk Republic }\end{array}$ & 104 & 37 & -353 & 424 & 71 & - \\
\hline
\end{tabular}


Table 2, cont'd

\begin{tabular}{|c|c|c|c|c|c|c|}
\hline RF subject & 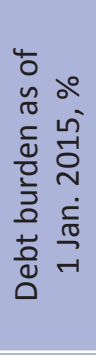 & 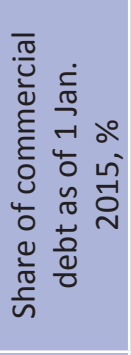 & 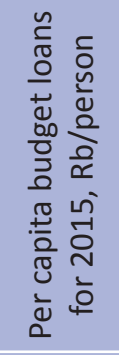 & 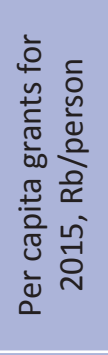 & 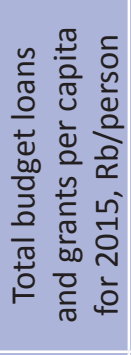 & 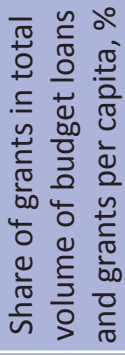 \\
\hline Republic of Mordovia & 121 & 36 & 2472 & 1041 & 3513 & 30 \\
\hline Republic of Ingushetia & 113 & 0 & 2103 & 2635 & 4737 & 56 \\
\hline $\begin{array}{l}\text { Chukotka Autonomous } \\
\text { Okrug }\end{array}$ & 144 & 0 & -19412 & 14799 & -4613 & - \\
\hline RF on the whole & 35 & 64 & 1144 & 1042 & 2186 & 48 \\
\hline $\begin{array}{l}\text { RF on the whole (without } \\
\text { Moscow and Crimean FD) }\end{array}$ & 44 & 62 & 1271 & 991 & 2262 & 44 \\
\hline
\end{tabular}

Sources: Federal Treasury, authors' calculations.

Analysis of Table 2 data as a whole does not allow to reveal a clear dependence of extended budget loans and grants intended to balance regional budgets in 2015 on the value of debt burden of RF subjects as of the beginning of 2015 and share of commercial debt in the structure of regions' debt. However, replacement of commercial credits with budget loans is observed in a number of regions. In 8 regions (out of 24 regions reviewed in Table 2) the volume of commercial debt in the structure of debt fell during 2015: Republic North Ossetia Alania (-43\%), Kirov oblast (-34\%), Astrakhan oblast $(-11 \%)$, Novgorod oblast (-9\%), Zabaikalsky Krai (-6\%), Ryazan oblast (-2\%), Vologda oblast $(-2 \%)$, Kostroma oblast $(-1 \%)$. At the same time, during 2015, 10 regions (of 24) on the contrary were building up their commercial debt: Republic of Mai El (+15\%), Karachaevo-Cherkessk Republic $(+11 \%)$, Republic of Khakasia $(+9 \%)$, Republic of Mordovia $(+8 \%)$, Orel oblast $(+5 \%)$, Amur oblast $(+3 \%)$, Pskov oblast $(+2 \%)$, Krasnodarsky Krai $(+2 \%)$, Saratov oblast $(+1 \%)$, Republic of Karelia (+1\%).

Fig. 1 and 2 demonstrate more vividly the lack of clear dependence of the volume (per capita) of allocated funds on the regions' debt burden as of the beginning of the year

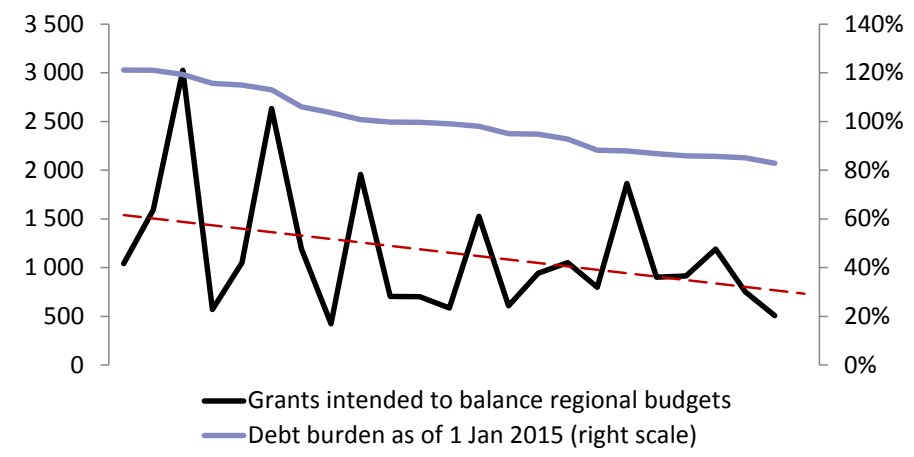

Note. Less Chukotka Autonomous Okrug.

Sources: Federal Treasury, Finance Ministry of Russia.

Fig. 1. Volume of grants intended to balance regional budgets and debt burden as of beginning of year (24 regions)

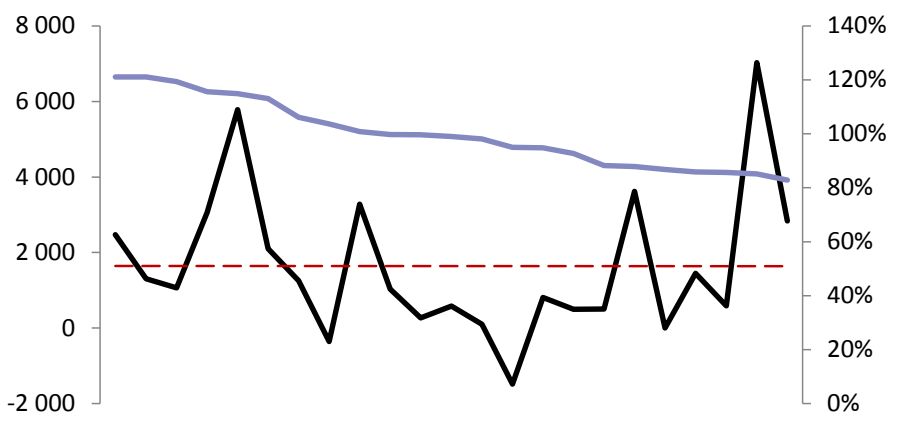

-Budget credits, Rb/person —Debt burden as of 1 Jan. 2015 (right scale)

Note. Less Chukotka Autonomous Okrug.

Sources: Federal Treasury, Finance Ministry of Russia.

Fig. 2. Volume of budget credits per capita in 2015 and debt burden as of 1 January 2015 (24 regions) 
(in group of regions with high debt burden of over $80 \%$ ).

We conducted further analysis regarding dependence of budget credits and grants on balance of regional budgets in 2015 depending on dynamics of tax and nontax revenues of the RF subjects in H1 2015 against the same period of 2014 (Fig. 3). We asked ourselves a question, was it really via interbudgetary instruments the "prompt" financial support was provided above all to the regions facing problems with revenue side of the budgets in the course of the year? ${ }^{1}$ Given below figure shows that dynamics of tax and non-tax revenues of regional budgets in $\mathrm{H} 1$ apparently was not the main indicator taken by the Finance Ministry of Russia as a benchmark for allocation of additional financial support.

Additionally, we analyzed an issue as to whether during 2015 the volumes of additional aid (budget credits and grants intended to balance regional budgets) to a greater degree were affected by dynamics of tax and non-tax revenues of the regional budgets as of the periodend for 2014 (against 2013, Fig. 4). If we exclude RF subjects with maximum and minimum values regarding reviewed indicators, the Figure

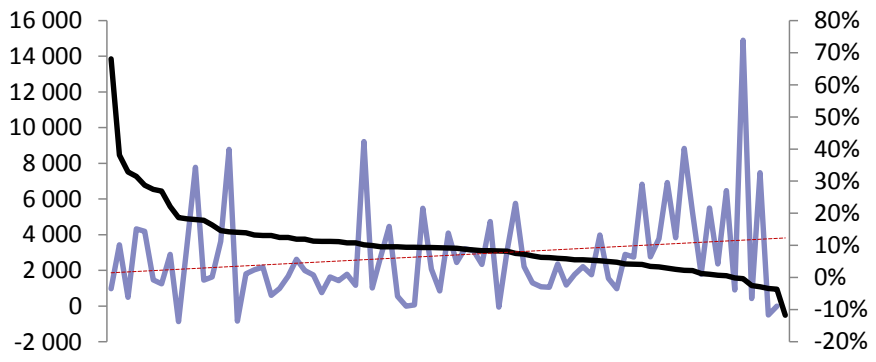

_Total volume of credits and grants per capita for $2015, \mathrm{Rb} /$ person (left scale)

-Tax and non-tax revenues for H1 2015, growth in \% (right scale)

Sources: Federal Treasury, Finance Ministry of Russia, authors' calculations.

Fig. 3. Total volume of budget credits and grants intended to balance regional budgets per capita in 2015 and dynamics of tax and non-tax revenues in H1 2015 (all RF subjects)

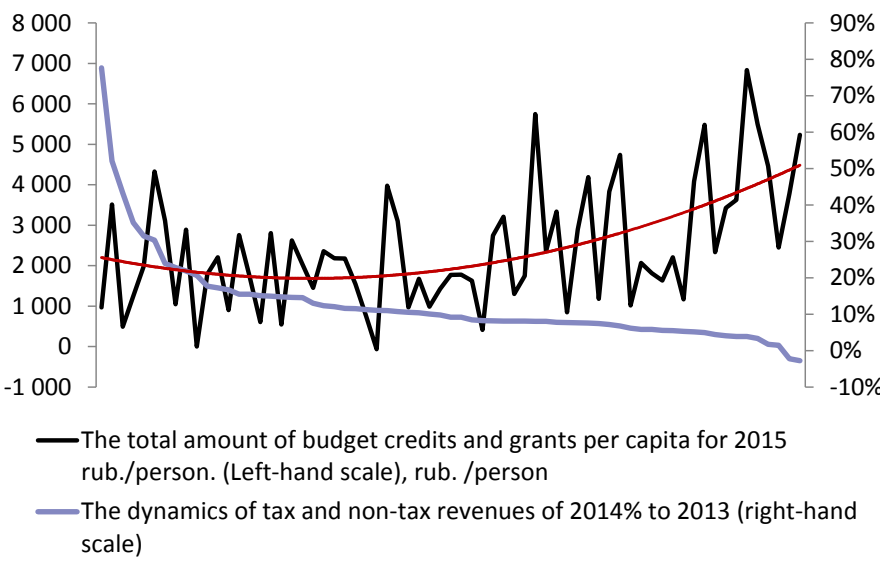

Sources: Federal Treasury, Finance Ministry of Russia, authors' calculations.

Fig. 4. Total volume of budget credits and grants intended to balance regional budgets (per capita) in 2015 and dynamics of tax and non-tax revenues of regional budgets in 2014 (less maximum and minimum values) shows certain regularity: with a decrease of growth rate of tax and non-tax revenues in 2014, general volume of "prompt" financial aid somewhat increased on average as of the period-end for 2015. Nevertheless, a significant range of values is observed regarding volumes of budget credits and grants intended to balance regional budgets. Subsequently, we can say that other factors exerted no less but even greater influence while determining volumes of additional financial aid.

Finally, let us analyze main indicators used in the aforementioned analysis separately for 7 RF subjects which were identified as regions which received absolute maximum volumes of financial aid both in terms of grants intended to balance regional budgets and in terms of budget credits (Table 3).

1 In order to facilitate analysis it is assumed that additional volumes are primarily allocated in $\mathrm{H} 2$ based on results of regional budgets execution carried out in $\mathrm{H} 1$. Partially, this reflects real practice. 
Table 3

SAMPLED BUDGET INDICATORS ON 7 RF SUBJECTS WITH MAXIMUM VOLUMES OF BUDGET CREDITS AND GRANTS INTENDED TO BALANCE REGIONAL BUDGETS IN 2015

\begin{tabular}{|c|c|c|c|c|c|c|c|c|}
\hline & 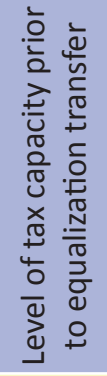 & 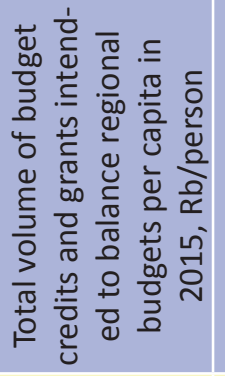 & 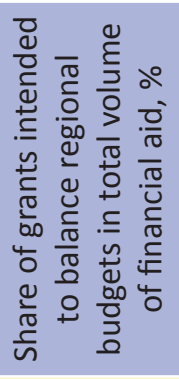 & 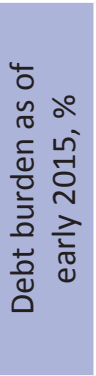 & 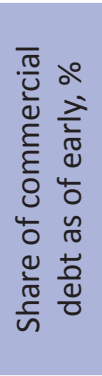 & 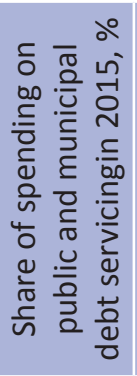 & 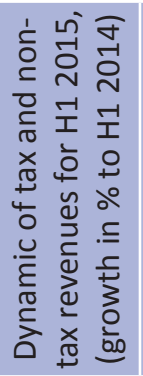 & 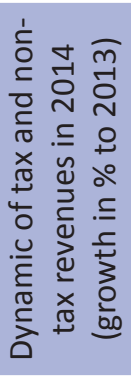 \\
\hline $\begin{array}{l}\text { Average on } \\
\text { Russia }\end{array}$ & 1.000 & 2186 & 48 & 35 & 64 & 1.6 & 12.3 & 9 \\
\hline Khabarovsk Krai & 0.776 & 8837 & 21 & 42 & 78 & 2.0 & 2.2 & 2 \\
\hline $\begin{array}{l}\text { Arkhangelsk } \\
\text { oblast }\end{array}$ & 0.593 & 5750 & 32 & 72 & 66 & 2.1 & 7.5 & 6 \\
\hline Primorsky Krai & 0.717 & 3979 & 39 & 14 & 79 & 0.9 & 5.2 & 7 \\
\hline Perm Krai & 0.894 & 3778 & 25 & 17 & 83 & 0.3 & 3.3 & -5 \\
\hline Krasnoyarsk Krai & 0.900 & 3426 & 23 & 60 & 84 & 2.9 & 38.1 & 5 \\
\hline Samara oblast & 1.148 & 2336 & 56 & 49 & 81 & 3.2 & 8.4 & 3 \\
\hline $\begin{array}{l}\text { Sverdlovsk } \\
\text { oblast }\end{array}$ & 1.099 & 1814 & 30 & 35 & 84 & 1.5 & 13.9 & 1 \\
\hline
\end{tabular}

Note. Debt burden indicator is given for the budgets of RF subjects, and dynamics of tax and non-tax revenues is given for the consolidated budgets of RF subjects.

Sources: Federal Treasury, Finance Ministry of Russia, own calculations.

Reviewed 7 regions significantly differ across volumes of "prompt" financial aid in terms of per capita. At the same time, in this group there are RF subjects with different level of calculated tax capacity (prior to distribution of grants for 2015). In the meantime, general per capita volumes of budget credits and grants designed to balance regional budgets have no clear correlation with a single of reviewed budget indicators: debt burden, share of commercial debt, share of spending on debt servicing, and movement of tax and non-tax revenues. At the same time, as in the analysis across all regions, some correlation is observed solely with dynamic of revenues less transfers in 2014 (i.e. with 1-year lag): regarding this indicator, all regions were below average value across Russia. However, this indicator does not explain differences in volumes of financial aid inside this group.

What major conclusions can be drawn from this analysis? First, significant volumes of "prompt" federal financial aid transferred to regions via instruments of budget credits and grants intended to balance regional budgets are concentrated in a limited group of RF subjects. Second, there are regions, which concentrate significant amounts of both credits and grants. However, the share of such regions turned out to be below $50 \%$ (7 out of 20 in each group with maximum volumes of credits and grants respectively, total 7 out of 33). Accordingly, various regions were supported via these instruments. Third, volumes of "prompt" federal financial aid to regions are barely correlated with such indicators, which reflect the scale of problems in regional finances, as the level of debt burden (including share of expensive in servicing commercial debt) and movement of tax and non-tax revenues.

Incidentally, one cannot say that allocated volumes of financial aid do not correlate at all with any indicators and are allocated arbitrarily. In our case, 
another factor is paramount: volumes of budget credits and grants designed to balance regional budgets have turned out to be barely correlated with the most simple, transparent and comparable among regions indicators, which reflect the magnitude of problems during the regional budgets execution. This significantly reduces transparency and justification of usage of these tools for interbudgetary relations. This can create conditions for soft budget constraints for subnational authorities and thus worsen their fiscal incentives.

The lack of correlation can also be indicative of a conflict between the objectives of interbudgetary relations regulation and applied budget instruments. Allocation of a share of grants to balance regional budgets in order to offset additional regional budgets spending serves as a striking example of such practice. As a matter of fact, these grants serve as subsidies. Such practice also decreases efficiency and transparency of interbudgetary relations.

Distribution of grants designed to balance regional budgets has an element of politics. This is reflected in the fact that maximum volumes of financial aid were sent to Chechnya and Crimea. The amount of additional financial aid depends on the political heft and consequently lobbying capacity of specific governor. All this results in the fact that total distributed amounts hardly correlate with general and objective indicators, which reflect the scale of the problem manifested in regional finances. 